\title{
Pengembangan Media Baret Berbasis Android untuk Meningkatkan Kemampuan Pemahaman Konsep Matematis Siswa SMK
}

\author{
Yesi Lusiana Septia ${ }^{1}$, Novi Andri Nurcahyono ${ }^{2}$, Pujia Siti Balkist ${ }^{3}$ \\ 1, 2, 3 Program Studi Pendidikan Matematika, Fakultas Keguruan dan Ilmu Pendidikan, Universitas Muhammadiyah \\ Sukabumi, Jl. R. Syamsudin, SH. No. 50 \\ Yesilusianasept@gmail.com
}

\begin{abstract}
This study aims to determine: (1) validity, (2) practicality and, (3) effectiveness on android-based mobile learning media. This type of research is Research and Development research. In this study using the ADDIE development model. The research subjects were teachers, 25 students of class X Accounting at SMK Hassina and the validators. The instruments used in this study were material expert validation sheets and media experts to obtain media validity test results as well as teacher and student response questionnaires to measure the practicality of the media and students' mathematical concept understanding ability tests to obtain effective results from the media. The results of the feasibility assessment by the validator showed that the media received an assessment of $88.33 \%$ from media experts and $84.61 \%$ from material experts, so it was very valid and worthy to be tested. The results of the trial obtained responses that were $84.615 \%$ from teachers and $86.363 \%$ from students, so the product was included in the very practical category. Then the results of student test analysis based on the scoring guidelines for understanding mathematical concepts obtained an initial total score of 253 and a final total score of 574. Based on the N-Gain test, an average result of $72.55 \%$ was obtained in the high category.
\end{abstract}

Keywords: ADDIE, Mobile Learning, Ability to understand Mathematical Concepts

\begin{abstract}
Abstrak
Penelitian ini bertujuan untuk mengetahui : (1) validitas, (2) kepraktisan dan , (3) efektivitas pada media mobile learning berbasis android. Jenis penelitian ini adalah penelitian Research and Development. Pada penelitian ini menggunakan model pengembangan ADDIE. Subjek penelitian adalah guru, 25 siswa kelas X Akuntansi SMK Hassina dan para validator. Instrumen yang digunakan pada penelitian ini yaitu lembar validasi ahli materi dan ahli media untuk memperoleh hasil uji validitas media serta angket respon guru dan siswa untuk mengukur kepraktisan dari media dan tes kemampuan pemahaman konsep matematis siswa untuk memperoleh hasil efektif dari media. Hasil penilaian kelayakan oleh validator menunjukkan bahwa media mendapat penilaian sebesar 88,33\% dari ahli media dan 84,61\% dari ahli materi, sehingga sangat valid dan layak untuk diuji cobakan. Hasil uji coba diperoleh respon yaitu 84,615\% dari guru dan 86,363\% dari siswa, sehingga produk termasuk kedalam kategori sangat praktis. Kemudian hasil analisis tes siswa berdasarkan pedoman penskoran pemahaman konsep matematis diperoleh skor total awal sebesar 253 dan skor total akhir sebesar 574. Berdasarkan uji N-Gain diperoleh hasil rata-rata sebesar 72,55\% dengan kategori tinggi.

Kata Kunci: ADDIE, Mobile Learning, Kemampuan Pemahaman Konsep Matematis
\end{abstract}

Copyright (c) 2021 Yesi Lusiana Septia, Novi Andri Nurcahyono, Pujia Siti Balkist

$\triangle$ Corresponding author: Yesi Lusiana Septia

Email Address: Yesilusianasept@gmail.com (J1. R. Syamsudin, SH. No. 50)

Received 11 August 2021, Accepted 31 August 2021, Published 22 December 2021

\section{PENDAHULUAN}

Perkembangan ilmu pengetahuan dan teknologi semakin berkembang dari masa ke masa dan telah mendorong inovasi-inovasi disegala bidang, salah satunya di bidang pendidikan. Dalam bidang pendidikan menjadi tantangan bagi guru untuk dapat mengintegrasikan teknologi dalam sistem pembelajaran, sehingga pembelajaran dapat bermakna, berkualitas dan menyenangkan. Hal tersebut sesuai dengan Permendikbud No.65 Tahun 2013 yang menyatakan bahwa kurikulum 2013 memfokuskan pada penggunaan TIK ke dalam proses pembelajaran, temasuk pembelajaran 
matematika.

Berdasarkan studi pendahuluan yang dilakukan disalah satu sekolah SMK kabupaten Sukabumi, media pembelajaran masih jarang digunakan serta kurangnya ketersedian buku paket. Berdasarkan hasil observasi, diperoleh hasil bahwa kemampuan pemahaman konsep matematis masih tergolong rendah. Hal ini disebabkan pembelajaran matematika selalu dimulai dengan objek yang abstrak (Ricard dalam Supriatna \& Nurcahyono, 2017). Selain itu dapat dipengaruhi dari kegiatan pembelajaran dikelas salah satunya cara mengajar guru yang monoton sehingga membuat siswa bosan saat kegiatan pembelajaran (Astuti et al., 2018). Hal tersebut didukung oleh (Nurcahyono \& Novarina, 2020) yang menyatakan kurangnya kreativitas serta inovasi guru dalam kegiatan pembelajaran matematika membuat siswa tidak tertarik. Adapun penyebab lainnnya yaitu waktu yang terbatas saat pembelajaran dikelas membuat siswa merasa kesulitan dalam memahami konsep materi yang banyak termasuk pelajaran matematika (Lestari et al., 2019).

Untuk menanggulangi permasalahan tersebut maka perlu digunakannya bahan pembelajaran yang berkaitan dengan konteks nyata siswa (Komalasari dalam Supriyatna dan Nanurcahyono, 2017). Salah satunya menggunakan media pembelajaran yang memanfaatkan teknologi. Saat ini teknologi perangkat mobile khususnya smartphone sudah tidak asing lagi di golongan pelajar. Sistem operasi yang banyak digunakan pada mobile (smartphone) adalah android (Setiawan et al., 2014). Berdasarkan kuesioner yang disebarkan kepada siswa SMK Kabupaten Sukabumi kelas X sebanyak 217 siswa memiliki smartphone berbasis android atau sekitar 97\% dari jumlah siswa. Hal ini menjadi potensi untuk mengoptimalkan pemanfaatan smartphone sebagai media pembelajaran yang didukung dengan siswa setuju jika diadakannya pembelajaran menggunakan perangkat mobile atau yang disebut mobile learning (Apriyanto \& Hilmi, 2019).

Mobile learning merupakan pembelajaran yang memanfaatkan IT menggunakan mobile untuk belajar dan mengakses materi kapanpun dan dimanapun. Hal ini salah satu bentuk pemanfaatan teknologi multimedia yang bersifat interaktif artinya mobile learning memiliki konten pembelajaran seperti tulisan, gambar, audio, dan video (El husein dalam Hartanto, 2016) yang membantu siswa cepat memahami konsep terhadap materi pelajaran (Ariputri et al., 2015).

Berdasarkan hasil pengembangan yang dilakukan Purbasari (2013) dan Kusuma (2016) menunjukkan bahwa media yang dikembangkan hanya memfokuskan pada materi saja, belum dicantumkannya latihan soal yang membantu untuk melatih meningkatkan kemampuan siswa. karena itu peneliti akan mengembangkan media mobile learning berbasis android terhadap kemampuan pemahaman konsep matematis siswa yang didalamnya terdapat uraian materi, contoh soal dan pembahsan melalui video serta latihan soal untuk berlatih yang bersifat interaktif.

\section{METODE}

Penelitian ini menggunakan metode Research and Development (R\&D) yaitu penelitian yang menghasilkan suatu produk yang diuji kevalidan, kepraktisan dan keefektifan (Sugiyono, 2018). 
Produk yang dihasilkan yaitu media mobile learning berbasis android berupa aplikasi dengan bantuan web Kodular. Penelitian ini menggunakan model pengembangan ADDIE (Analysic, Design, Development, Implementation, Evaluation) sebab langkah- langkah urutan dalam prosesnya tersusun secara jelas serta sisematis (Sugihartini \& Yudiana, 2018). Adapun langkah- langkah penelitian dan pengembangan ADDIE dapat dilihat pada tabel berikut:

Tabel 1. Langkah - Langkah ADDIE

\begin{tabular}{|c|c|c|}
\hline Langkah & Kegiatan & Instrumen \\
\hline Analysis & $\begin{array}{l}\text { Menganalisis suatu permasalahan } \\
\text { dan kebutuhan }\end{array}$ & $\begin{array}{l}\text { 1. Analisis kebutuhan } \\
\text { 2. Analisis media }\end{array}$ \\
\hline Design & $\begin{array}{l}\text { Membuat rancangan desain produk, } \\
\text { pengumpulan referensi, menyusun } \\
\text { instrumen }\end{array}$ & $\begin{array}{l}\text { 1. Instrumen tes kemampuan } \\
\text { pemahaman konsep matematis } \\
\text { 2. Instrumen validasi produk } \\
\text { 3. Instrumen kepraktisan produk } \\
\text { 4. Instrumen keefektifan produk }\end{array}$ \\
\hline Devolopment & $\begin{array}{l}\text { Merealisasikan produk berdasarkan } \\
\text { rancangan }\end{array}$ & $\begin{array}{l}\text { 1. Merealisasikan rancangan menjadi } \\
\text { suatu produk } \\
\text { 2. Validasi produk } \\
\text { 3. Validasi instrumen tes }\end{array}$ \\
\hline Implementation & Mengimplementasikan produk & $\begin{array}{l}\text { 1. Angket respon guru dan siswa } \\
\text { 2. Instrumen tes kemampuan } \\
\text { pemahaman konsep matematis }\end{array}$ \\
\hline Evaluation & $\begin{array}{l}\text { Menilai kualitas produk dan proses } \\
\text { pembelajaran sebelum dan sesudah } \\
\text { penggunaan media. }\end{array}$ & $\begin{array}{l}\text { 1. Hasil angket respon guru dan siswa } \\
\text { 2. Hasil tes kemamapuan pemahaman } \\
\text { konsep matematis }\end{array}$ \\
\hline
\end{tabular}

Data kuantitatif diperoleh dari hasil penyebaran angket yang berskala likert sebab digunakan untuk mengukur sikap, pendapat, dan persepsi seseorang atau kelompok tentang kasus (Sugiyono, 2018). Analisis kevalidan produk dapat dihitung menggunakan rumus sebagai berikut (Azis et al., 2019):

$$
\text { Validitas }=\frac{\text { Jumlah skor yang diperoleh }}{\text { Jumlah skor maksimum }} \times 100 \%
$$

Setelah diperoleh hasil, kemudian hasil tersebut diinterpretasikan dengan kriteria kevalidan sebagai berikut:

Tabel 2. Kriteria kevalidian produk

\begin{tabular}{|c|c|}
\hline Penilaian & Kategori \\
\hline $0 \%-20 \%$ & Sangat Tidak Valid \\
\hline $21 \%-40 \%$ & Tidak Valid \\
\hline $41 \%-60 \%$ & Cukup Valid \\
\hline $61 \%-80 \%$ & Valid \\
\hline $81 \%-100 \%$ & Sangat Valid \\
\hline
\end{tabular}

(Sulistyaningrum, 2018)

Produk dikatakan valid apabila skor rata-rata minimal berada pada rentang valid yaitu $41 \%$ $60 \%$ (Subekti, 2014). Analisis kepraktisan produk dapat dihitung menggunakan rumus berikut (Azis et al., 2019): 


$$
\text { Kepraktisan }=\frac{\text { Jumlah skor yang diperoleh }}{\text { Jumlah skor maksimum }} \times 100 \%
$$

Setelah diperoleh hasil, kemudian hasil tersebut diinterpretasikan dengan kriteria kepraktisan sebagai berikut (Sulistyaningrum, 2018):

Tabel 3. Kriteria kepraktisan produk

\begin{tabular}{|c|c|}
\hline Penilaian & Kategori \\
\hline $0 \%-20 \%$ & Sangat Tidak Praktis \\
\hline $21 \%-40 \%$ & Kurang Praktis \\
\hline $41 \%-60 \%$ & Cukup praktis \\
\hline $61 \%-80 \%$ & Praktis \\
\hline $81 \%-100 \%$ & Sangat Praktis \\
\hline
\end{tabular}

Produk dikatakan praktis jika skor dari rata-rata guru dan siswa minimal berada pada rentang praktis yaitu 61\%-80\% (Subekti, 2014). Serta data kuantitatif juga diperoleh dari nilai pretest dan posttest untuk mengukur keefektifan dan peningkatan kemampuan pemahaman konsep matematis siswa. Pinunggul (2018) mengatakan produk efektif jika memenuhi ketuntasan klasikal dengan persentase $\geq$ 75\% dan adanya peningkatan hasil belajar siswa berada pada kategori sedang sampai tinggi (Nainggolan, Demita A.Y dan Simanjuntak, 2021).

Analisis keefektifan produk dapat dihitung menggunakan analisis ketuntasan klasikal dan analisis N-gain dengan rumus sebagai berikut:

\section{Rumus Analisis Ketuntasan Klasikal}

$$
\text { Tuntas belajar }=\frac{\text { banyak siswa yang tuntas }}{\text { banyak siswa seluruhnya }} \times 100 \%
$$

(Rosna, 2016)

\section{Rumus Analisis N-gain}

$$
N-\text { Gain }=\frac{\text { skor } \text { postttes-skor pretest }}{\text { Skor maks-skor pretes }} \times 100
$$

Tabel 4. Kriteria N-gain

\begin{tabular}{|c|c|}
\hline Skor & Kriteria \\
\hline $\mathrm{N}$-gain $<30$ & Rendah \\
\hline $30 \leq \mathrm{N}$-gain $\leq 70$ & Sedang \\
\hline $\mathrm{N}$-gain $>70$ & Tinggi \\
\hline
\end{tabular}

Sedangkan data kualitatif diperoleh dari penyebaran angket yang sebarkan kepada para ahli berupa lembar validasi serta kepada guru dan siswa berupa angket respon terhadap penggunaan media.

\section{HASIL DAN DISKUSI}

\section{Analysis (Analisis)}

Tahap ini dilakukannya analisis kebutuhan dan ketersedian media. Berdasarkan hasil observasi, media pembelajaran masih jarang digunakan dan kurangnya buku paaket sehingga diperlukannya media untuk meningkatkan kemampuan pemahaman siswa dengan memanfaatkan teknologi yang sudah tidak asing di golongan pelajar yaitu perangkat mobile khususnya smartphone. Media mobile 
learning yang diharapkan didalamnya terdapat gambar, contoh soal dan pembahasannya, audio, video, yang mempermudah siswa untuk memahami materi yang disampaikan serta tampilan yang menarik.

\section{Design (Perancangan)}

Pada tahap ini dimulai dari penyusunan kebutuhan media, menentukan nama media,merancang desain media, pengumpulan referensi dan menyusun instrumen penelitian. Berikut penjabarannya:

\section{Penyusunan Kebutuhan Media}

Penyusunan kebutuhan ini untuk mengetahui kebutuhan yang tedapat dalam media. Media disesuaikan dengan kompetensi dasar dan indikator pencapaian kompetensi. Serta penentuan aplikasi, penyusunan layout, video.

\section{Membuat Rancangan Design Media}

Pada tahap ini, melakukan rancangan produk sebagai gambaran dalam proses pengembangan diantaranya alur navigasi, flowchart serta storyboard. Berikut ini alur navigasi produk dan flowchart.

\section{Rencana Isi Media Mobile Learninig}

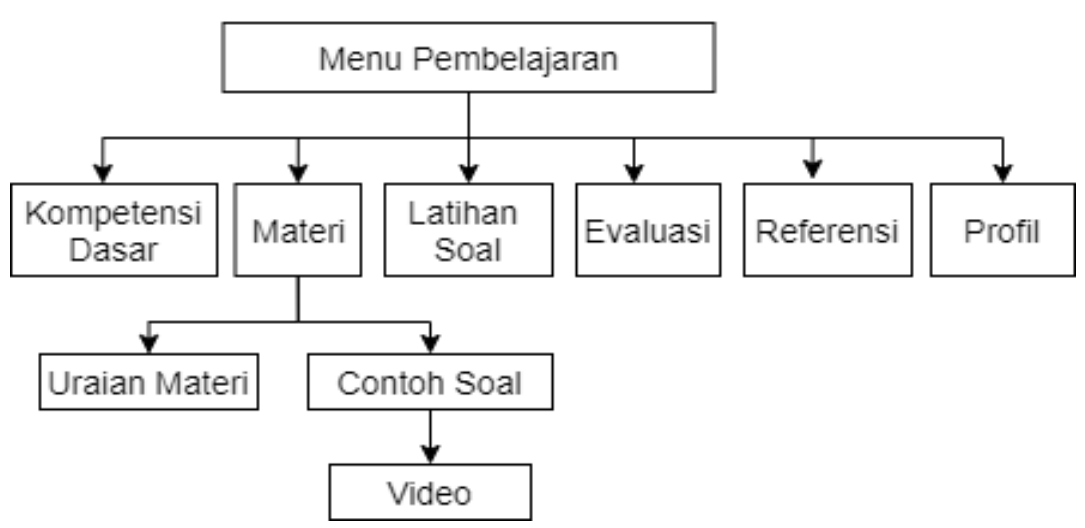

Gambar 1. Bagan Alur Navigasi Media BARET

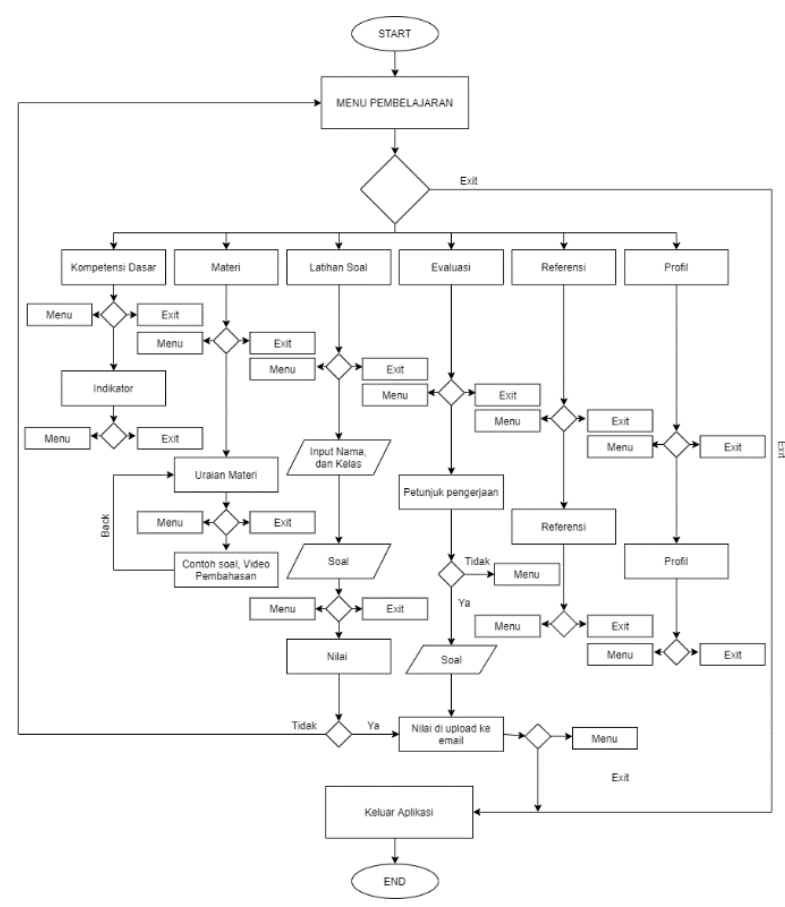

Gambar 2. Bagan Flowchat Media BARET 


\section{Menentukan Nama Media}

Pada tahap ini nama media berdasarkan singkatan dari materi yang dicantumkan dalam media.

\section{Pengumpulan Referensi}

Tahap ini peneliti mengumpulkan referensi mengenai materi, contoh soal, latihan soal dan gambar-gambar yang menjadi referensi untuk pembuatan media melalui buku, internet dan sumber lain.

\section{Menyusun Instrumen Penelitian}

Penyususnan instrumen penelitian diantaranya lembar penilaian kevalidan produk oleh ahli materi dan ahli media. Serta angket respon guru dan siswa untuk memperoleh hasil kepraktisan dari produk dan tes kemampuan pemahaman konsep matematis untuk memperoleh hasil keefektifan dari produk.

\section{Development (Pengembangan)}

Setelah merancang desain, tahap selanjutnya adalah merealisasikan rancangan menjadi produk. Selanjutnya produk tersebut divalidassi oleh ahli materi dan ahli media. Berikut ini beberapa tahapannya

\section{Pembuatan Media Mobile Learning}

Media mobile learning ini dikembangkan menggunakan web Kodular dengan bantuan aplikasi pendukung seperti Canva untuk mendesain background media dan gambar. Serta Benime untuk mengedit video yang terdapat dalam media. Menu pembelajaran yang tercantum dalam media diantaranya kompetensi dasar, materi, latihan soal, evaluasi, referensi dan profil. Berikut ini tampilan media mobile learning berbasis android.

\section{Halaman Awal}

Halaman awal merupakan tampilan awal media sebelum masuk ke menu pembelajaran

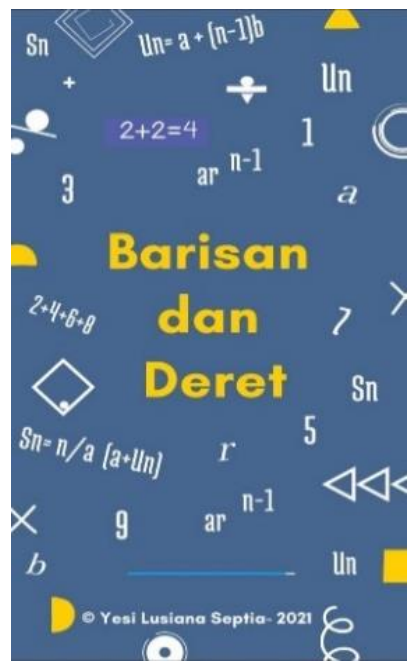

Gambar 3. Tampilan Halaman Awal

Menu Pembelajaran

Menu pembelajaran berisi menu kompetensi dasar, materi, latihan soal, evaluasi, referensi dan profil. 


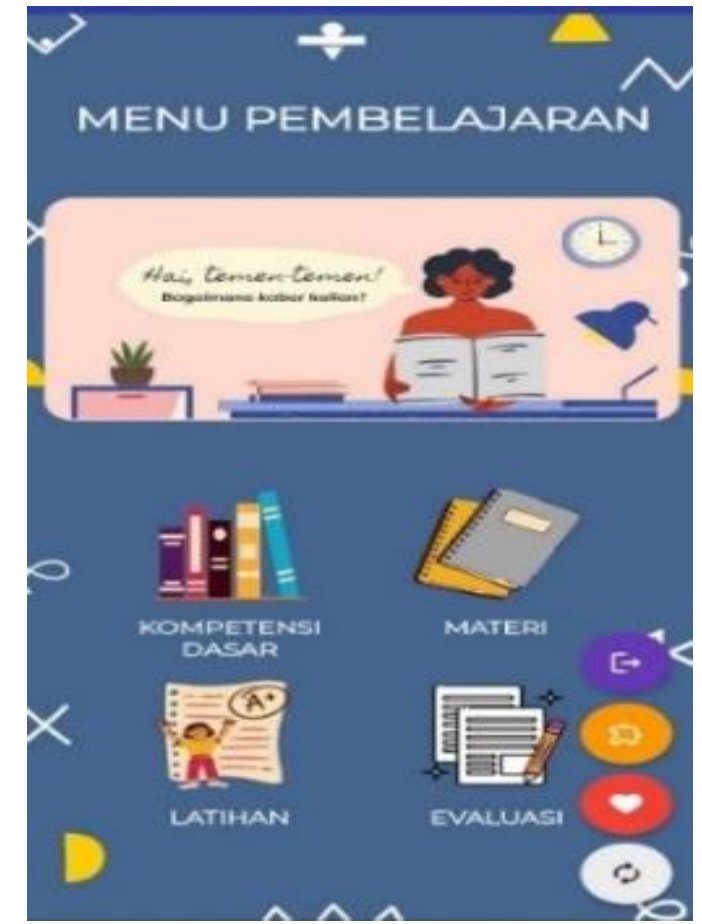

Gambar 4. Tampilan Menu Pembelajaran

Kompetensi dasar

Kompetensi dasar terdiri dari kompetensi dasar dan indikator pencapaian

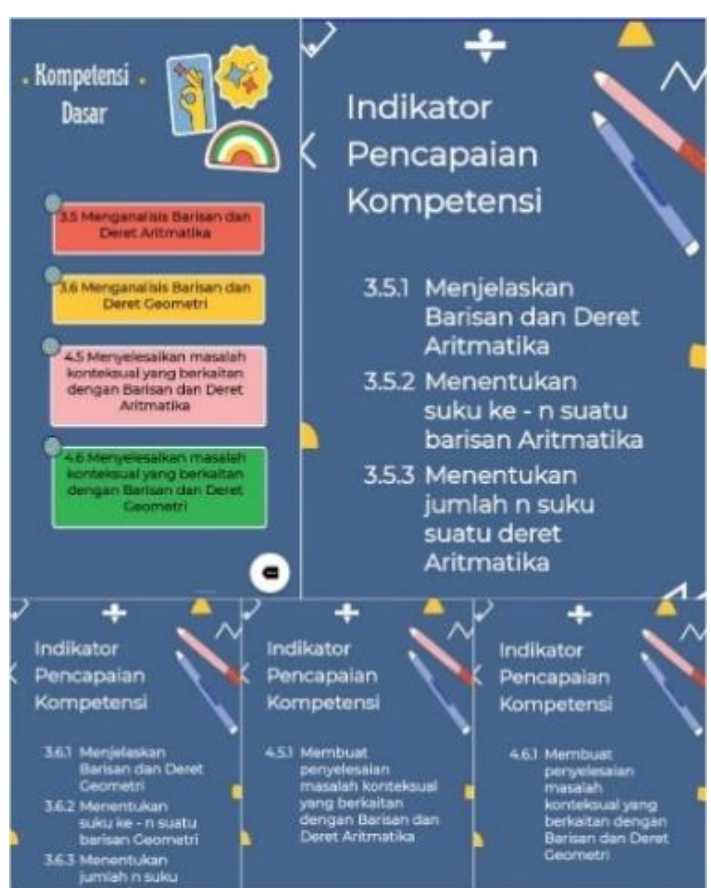

Gambar 5. Tampilan Kompetensi dasar

Materi

Menu materi terdiri dari materi barisan dan deret yang terdapat lima button yaitu barisan deret, barisan aritmatika, deret aritmatika, barisan geometri dan deret geometri. Setiap materi terdapat uraian materi, rumus dan contoh soal berupa video pembahasan. 


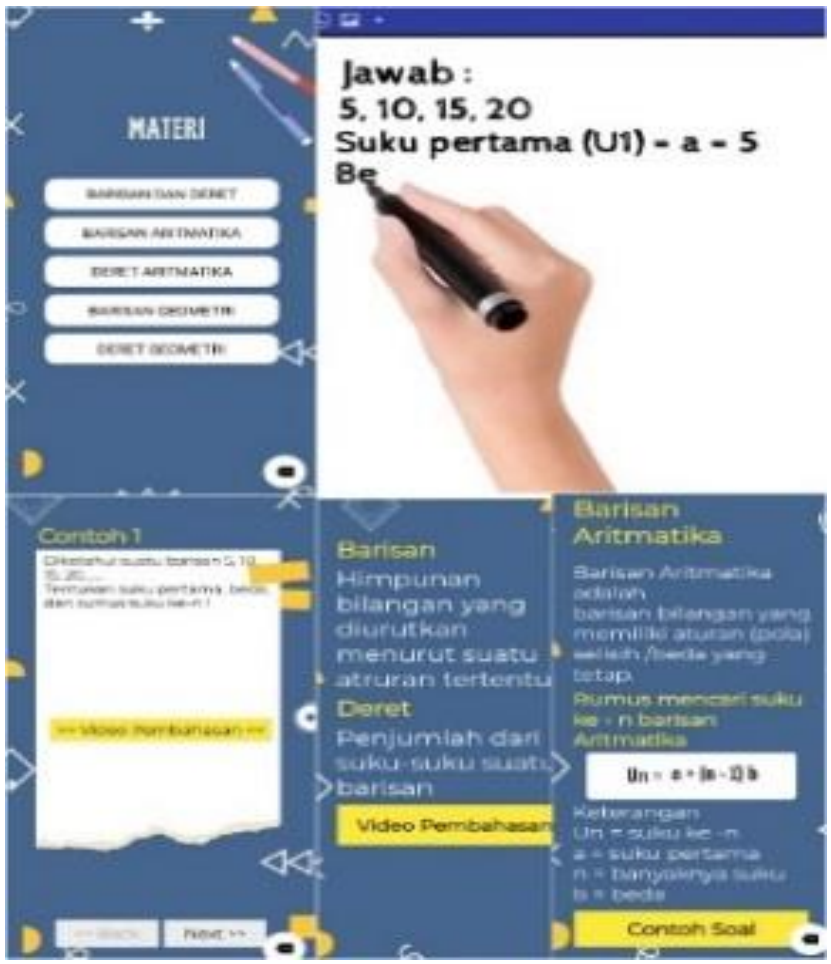

Gambar 6. Tampilan Materi

\section{Latihan Soal}

Latihan soal terdiri dari soal-soal semua materi barisan deret berupa soal pilihan ganda yang sesuai dengan indikator kemampuan pemahaman konsep. Dalam latihan soal ini skor yang diperoleh siswa akan ditampilkan.

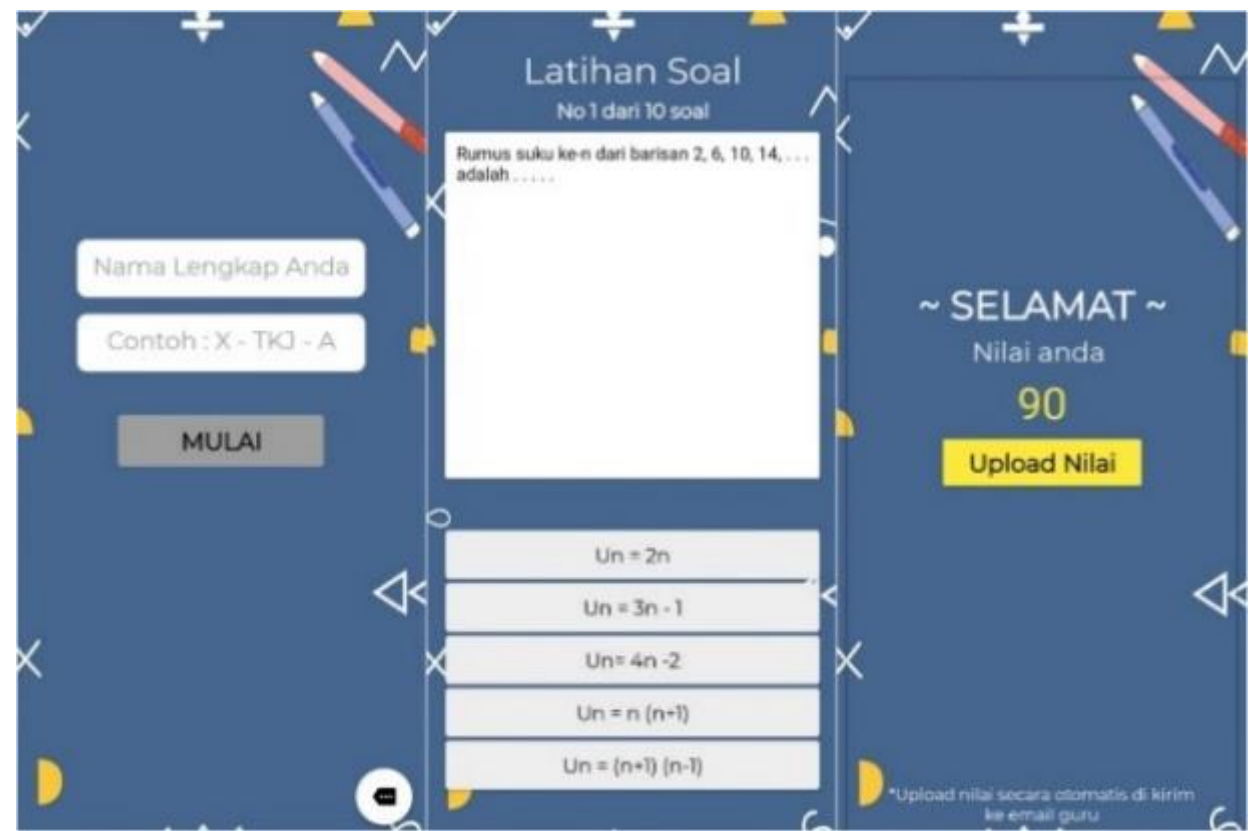

Gambar 7. Tampilan Latihan Soal

\section{Evaluasi}

Evaluasi terdiri dari soal uraian yang sesuai dengan indikator kemampuan pemahaman konsep dan siswa dapat meng Upload lembar jawaban. 


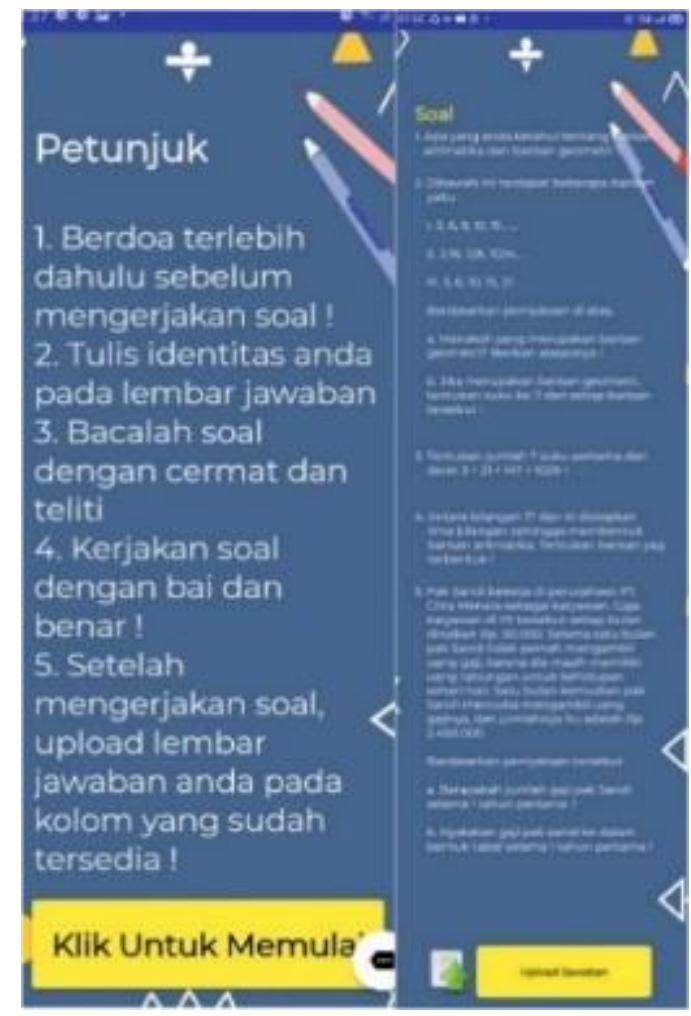

Gambar 8. Tampilan Evaluasi

\section{Validitas Media Mobile Learning}

Penilaian validitas media BARET diperoleh dari ahli materi dan ahli media. Data kualitatif diperoleh dari kritik dan saran ahli materi dan ahli media untuk melengkapi kekurangan yang terdapat pada media yang sudah dikembangkan. Adapun data kualitatf dan data kuantitaf dari hasil validasi produk oleh ahli materi dan ahli media dapat dilihat pada tabel berikut

Tabel 5. Data Kualitatif Hasil validasi Ahli Materi dan Ahli Media

\begin{tabular}{|c|c|c|c|}
\hline No & Validasi & Validator & Keputusan \\
\hline 1 & Ahli Materi & $\mathrm{Y} 1, \mathrm{Y} 2, \mathrm{Y} 3$ & $\begin{array}{l}\text { Media ini sudah layak untuk digunakan dengan } \\
\text { beberapa revisi untuk melengkapi media diantaranya } \\
\text { soal-soal yang terdapat di media dibuat soal } \\
\text { kemampuan pemahaman konsep matematis dan soal } \\
\text { yang kontekstual serta cantumkan petunjuk dalam } \\
\text { pengerjaan soal. Dan dibagian latihan soal, sebaiknya } \\
\text { siswa dapat mengisi soal di aplikasi tersebut serta } \\
\text { skornya ditampilkan untuk memicu siswa semangat } \\
\text { mengerjakan soal }\end{array}$ \\
\hline 2 & Ahli Media & $\mathrm{Z1}, \mathrm{Z2}, \mathrm{Z3}$ & $\begin{array}{l}\text { Sudah layak untuk digunakan dengan beberapa revisi } \\
\text { untuk melengkapi media diantaranya font yang } \\
\text { didalam media dirubah ke jenis font montserrat, } \\
\text { button back dan next nya dibikin beda warna dengan } \\
\text { background, button nya dirubah lebih proporsional, } \\
\text { tampilan user interface lebih ditonjolkan. }\end{array}$ \\
\hline
\end{tabular}

Tabel 6. Data Kuantitatif Hasil Validasi Ahli Materi dan Ahli Media

\begin{tabular}{|l|c|c|c|c|c|c|}
\hline \multicolumn{1}{|c|}{ Penyajian } & Y1 & Y2 & Y3 & Z1 & Z2 & Z3 \\
\hline Materi & 24 & 24 & 26 & - & - & - \\
\hline
\end{tabular}




\begin{tabular}{|c|c|c|c|c|c|c|}
\hline Penyajian & Y1 & Y2 & Y3 & $\mathbf{Z 1}$ & $\mathbf{Z 2}$ & $\mathbf{Z 3}$ \\
\hline Pembelajaran & 12 & 14 & 15 & - & - & - \\
\hline Kebahasaan & 16 & 16 & 18 & - & - & - \\
\hline Tampilan & - & - & - & 55 & 53 & 51 \\
\hline Jumlah Skor & 52 & 54 & 59 & 55 & 53 & 51 \\
\hline $\begin{array}{l}\text { Rata- rata jumlah } \\
\text { skor }(\%)\end{array}$ & $80 \%$ & $83,07 \%$ & $90,76 \%$ & $91,66 \%$ & $88,33 \%$ & $85 \%$ \\
\hline $\begin{array}{l}\text { Rata- rata jumlah } \\
\text { skor tototal }(\%)\end{array}$ & \multicolumn{3}{|c|}{$84,61 \%$} & \multicolumn{3}{|c|}{$88,33 \%$} \\
\hline kriteria & \multicolumn{3}{|c|}{ Sangat Valid } & \multicolumn{3}{|c|}{ Sangat Valid } \\
\hline $\begin{array}{l}\text { Keterangan: } \\
Y=\text { Ahli Materi } \\
Z=\text { Ahli Media } \\
\text { Skor Maksimal } Y=65 \\
\text { Skor Maksimal } Z=60\end{array}$ & & & & & & \\
\hline
\end{tabular}

Berdasarkan tabel diatas, diperoleh rata-rata dari validator yaitu sebesar $86,47 \%$ artinya skor tersebut masuk kedalam kategori sangat valid yaitu pada rentang $81 \%-100 \%$.

\section{Implementation (Implementasi)}

Tahap implementasi ini dilakukannya uji coba produk. Sebelum uji coba produk, peneliti mengenalkan produk kepada guru mata pelajaran matematika. Setelah itu peneliti memberikan soal pretest kepada siswa, kemudian mendistribusikan media mobile learning kepada siswa secara online yaitu berupa file android (.apk). Setelah itu siswa menginstall aplikasi BARET di handphone masingmasing.

Selanjutnya produk tersebut diujicobakan terhadap siswa kelas X Akuntansi di SMK Hassina Sukabumi sebanyak 25 orang. Setelah terinstalnya aplikasi BARET siswa diarahkan untuk mempelajari materi barisan dan deret. Setelah selesai menggunakan media mobile learning, peneliti memberikan soal posttest dan angket respon siswa untuk mengetahui keefektifan serta kepraktisan produk. Berikut penjabarannya.

\section{Hasil Pretest dan Posttest}

Pretest dan posttest berbentuk soal uraian sebanyak tujuh soal yang disusun berdasarkan indikator kemampuan pemahaman konsep matematis. Berikut ini adalah hasil yang diperoleh dari pretest dan posttest.

Tabel 7. Hasil Nilai Pretest dan Posttest Siswa

\begin{tabular}{|c|l|c|l|c|}
\hline No & Rentang Skor Pretest & $\begin{array}{c}\text { Jumlah } \\
\text { Siswa }\end{array}$ & $\begin{array}{c}\text { Rentang } \\
\text { Skor Posttest }\end{array}$ & $\begin{array}{c}\text { Jumlah } \\
\text { Siswa }\end{array}$ \\
\hline 1 & $0 \leq$ skor $\leq 6$ & 4 & $0 \leq$ skor $\leq 6$ & 0 \\
\hline 2 & $7 \leq$ skor $\leq 14$ & 19 & $7 \leq$ skor $\leq 14$ & 0 \\
\hline 3 & $15 \leq$ skor $\leq 21$ & 2 & $15 \leq$ skor $\leq 21$ & 5 \\
\hline 4 & $22 \leq$ skor $\leq 28$ & 0 & $22 \leq$ skor $\leq 28$ & 18 \\
\hline 5 & Skor $=28$ & 0 & Skor $=28$ & 2 \\
\hline \multicolumn{2}{|l}{ Skor total: 253} & 25 & Skor total: 574 & 25 \\
\hline
\end{tabular}


Kemudian nilai pretest dan posttest tersebut dianalisis menggunakan analisis $\mathrm{N}$-gain sebesar 72,553 dengan kategori tinggi serta ketuntasan klasikal sebesar 84\% yang artinya media mobile learning yang dikembangkan efektif untuk meningkatkan kemampuan pemahaman konsep matematis siswa.

\section{Hasil Penilaian Media Mobile Learning Berdasarkan Angket Respon Guru dan Siswa}

Analisis penilaian angket respon dilakukan setelah siswa menggunakan media mobile learning. Angket ini diberikan kepada guru dan 25 orang siswa yang telah menggunakan media mobile learning untuk mengetahui kepraktisan media tersebut. Adapun hasil penilaian media berdasarkan respon guru dan siswa dapat dilihat pada tabel berikut

Tabel 8. Hasil Penilaian Media Berdasarkan Respon Guru

\begin{tabular}{|c|c|c|c|c|c|c|}
\hline \multirow{2}{*}{ No } & Aspek yang & \multirow{2}{*}{$\begin{array}{c}\text { Butir } \\
\text { Dinilai }\end{array}$} & \multicolumn{2}{|c|}{ Skor } & \multirow{2}{*}{ Persentase } & \multirow{2}{*}{ Kriteria } \\
& pertanyaan & Total & Harapan & & \\
\hline 1 & Isi & 6 & & & & \\
\hline 2 & Penyajian & 4 & & & & \\
\hline 3 & Kebahasaan & 1 & \multirow{2}{*}{44} & 52 & 84,615 & Sangat Praktis \\
\hline 4 & Motivasi & 1 & & & & \\
\hline 5 & Kegunaan & 1 & & & & \\
\hline & Jumlah & 13 & & & &
\end{tabular}

Tabel 9. Hasil Penilaian Media Berdasarkan Respon siswa

\begin{tabular}{|c|c|c|c|c|c|c|}
\hline \multirow{2}{*}{ No } & \multirow{2}{*}{$\begin{array}{c}\text { Aspek yang } \\
\text { Dinilai }\end{array}$} & \multirow{2}{*}{$\begin{array}{c}\text { Butir } \\
\text { pertanyaan }\end{array}$} & \multicolumn{2}{|c|}{ Skor } & \multirow{2}{*}{ Persentase } & \multirow{2}{*}{ Kriteria } \\
\hline & & & Total & Harapan & & \\
\hline 1 & Isi & 360 & \multirow{6}{*}{950} & \multirow{6}{*}{1.100} & \multirow{6}{*}{86,363} & \multirow{6}{*}{ Sangat Prakti } \\
\hline 2 & Penyajian & 343 & & & & \\
\hline 3 & Kebahasaan & 84 & & & & \\
\hline 4 & Motivasi & 77 & & & & \\
\hline 5 & Kegunaan & 86 & & & & \\
\hline & Jumlah & 950 & & & & \\
\hline
\end{tabular}

Berdasarkan tabel ersebut diperoleh skor rata-rata sebesar $85,489 \%$ artinya produk yang dikembangkan termasuk dalam kategori sangat praktis. Selain itu guru dan siswa memberikan respon positif mengenai penggunanan media mobile learning yang menarik, dapat digunakan dan dapat memahami materi dengan baik.

\section{Evaluation (Evaluasi)}

Tahap evaluasi ini untuk mengetahui hasil akhir penilaian serta perlunya perbaikan pada media yang dikembangkan. Tahap evaluasi ini tidak hanya terletak pada tahap akhir tetapi ada pada setiap tahapan yaitu analysis, design, development, implementation yang disebut sebagai evaluasi formatif karena untuk revisi produk (Subekti, 2014). Sedangkan evaluasi sumatif adalah penilaian yang fokus terhadap hasil ketargetan kecapaian siswa (Priangga, 2021). 


\section{KESIMPULAN}

Berdasarkan hasil dan pembahasan dapat disimpulkan (1) Pengembangan media mobile learning berbasis android telah melaui tahap validasi produk dengan baik dan benar sehingga dapat menghasilkan produk yang valid. (2) Berdasarkan penyebaran angket respon, diperoleh hasil penilaian respon guru dan siswa terhadap media mobile learning termasuk dalam kategori sangat praktis serta guru dan siswa memberikan respon positif terhadap media. Sehingga dari hasil yang diperoleh berupa kevalidan, keefektifan dan kepraktisan menunjukkan bahwa media mobile learning yang sudah dikembangkan memiliki kualitas yang baik dan layak untuk digunalan dalam kegiatan pembelajaran. (3) Berdasarkan Analisis N-gain dan Analisis ketuntasan klasikal diperoleh skor pretest dan posttest siswa yang telah menggunakan media adanya peningkatan kemampuan pemahman konsep matematis siswa pada kategori tinggi. Hal ini menunjukkan bahwa media yang dikembangkan telah efektif dalam meningkatkan kemampuan pemahaman konsep matematis siswa

\section{UCAPAN TERIMA KASIH}

Peneliti mengucapkan terima kasih kepada Allah SWT yang telah memberikan kelancaran serta kemudahan dalam pelaksanaan penelitian ini. Peneliti juga sampaikan terima kasih keapada kedua orang tua tercinta dan orang-orang terdekat yang selalu memberikan doa, semangat serta dorongan. Dan peneliti sampaikan terima kasih kepada bapak Dr. Novi Andri Nurcahyono, M.Pd dan Ibu Pujia Siti Balkist, S.Si., M.Pd selaku dosen pembimbing yang telah memberikan arahan serta bimbingan selama penelitian dan penulisan artikel ini. Dan peneliti berterima kasih juga kepada para siswa serta validator yang sudah membantu berjalannya penelitian ini.

\section{REFERENSI}

Apriyanto, M. T., \& Hilmi, R. A. (2019). Media pembelajaran matematika (mobile learning) berbasis android. Seminar Nasional Penelitian Pendidikan Matematika (SNP2M), 115-124.

Ariputri, G. P., Supraptono, E., \& Suradi, T. (2015). Pengembangan Aplikasi Android untuk Pendukung Pembelajaran Listening Bahasa Inggris Kelas XI SMA. 16(4), 48-56.

Astuti, I. A. D., Dasmo, D., \& Sumarni, R. A. (2018). Pengembangan Media Pembelajaran Berbasis Android Dengan Menggunakan Aplikasi Appypie Di Smk Bina Mandiri Depok. Jurnal Pengabdian Kepada Masyarakat, 24(2), 695.

Azis, H. (2019). Pengembangan Bahan Ajar Fisika: Validitas, Realibilitas, Praktikalitas, Dan Efektifitas Bahan Ajar Cetak Meliputi Hand Out, Modul, Buku (Diktat, Buku Ajar, Buku Teks). In Journal of Wind Engineering and Industrial Aerodynamics (Vol. 26, Issue 3).

Hartanto, W. (2016). Inovasi Media Pembelajaran Mobile Learning. Seminar Nasional Pendidikan Ekonomi Jilid 2, 404-411.

Kusuma, D. (2016). Pengembangan Mobile Learning Matematika Sebagai Suplemen Pembelajaran Trigonometri Siswa SMA Kelas X. Universitas Kristen Satya Wacana. 
Lestari, A. I., Senjaya, A. J., \& Ismunandar, D. (2019). Pengembangan Media Pembelajaran Berbasis Android Menggunakan Appy Pie Untuk Melatih Pemahaman Konsep Turunan Fungsi Aljabar. Pedagogy: Jurnal Pendidikan Matematika, 4(2), 1-9.

Nainggolan, Demita A.Y dan Simanjuntak, E. (2021). PENGEMBANGAN LEMBAR KERJA PESERTA DIDIK (LKPD) BERBASIS PENDEKATAN METAKOGNITIF PADA MATERI POLA BILANGAN. Fibonacci, 1(1), 283.

Nurcahyono, N. A., \& Novarina, E. (2020). Analisis Rencana Pelaksanaan Pembelajaran Kurikulum 2013 Berdasarkan Indikator Kemampuan Imajinasi Matematis Siswa. JKPM (Jurnal Kajian Pendidikan Matematika), 6(1), 121.

Pinunggul, R. I., Darmadi, \& Apriandi, D. (2018). Pengembangan Media Pembelajaran Interaktif Dengan Visualisasi Menggunakan Adobe Flash Professional Pada Materi Segiempat Dan Segitiga Untuk Meningkatkan Prestasi Belajar Siswa. Prosiding Silogisme Seminar Nasional Pendidikan Matematika Universitas PGRI Madiun, 3, 152-158.

Priangga, Y. S. (2021). Pengembangan Media Pembelajaran Berbasis Aplikasi Smartphone Untuk Memfasilitasi Kemampuan Berpikir Kreatif Matematis Siswa. Jurnal Cendekia: Jurnal Pendidikan Matematika, 5(2), 1116-1126.

Purbasari, R. J. (2013). Pengembangan Aplikasi Android Sebagai Media Pembelajaran Matematika Pada Materi Dimensi Tiga Untuk Siswa SMA Kelas X. Universitas Negeri Malang.

Rosna, A. (2016). Meningkatkan Hasil Belajar Siswa Melalui Pembelajaran Kooperatif Pada Mata Pelajar IPA di kelas IV SD Terpencil Bainaa Barat. Jurnal Kreatif Tadulako Online, 04(6), 235 246.

Setiawan, Astuti, I. F., \& Khairina, D. M. (2014). Rancang Bangun Game Edukasi Berbasis Android Tebak Lagu Nusantara: Senara | Setiawan | Informatika Mulawarman: Jurnal Ilmiah Ilmu Komputer. Informatika Mulawarman, 9(2), 24-30.

Subekti, F. E. (2014). Pengembangan Perangkat Pembelajaran Matematika Kelas X SMK Dengan Model Problem Solving Heuristic Berprinsip Pengelolaan Laboratorium Teenzania. Euclid, 1(2), $104-115$.

Sugihartini, N., \& Yudiana, K. (2018). Addie Sebagai Model Pengembangan Media Instruksional Edukatif (Mie) Mata Kuliah Kurikulum Dan Pengajaran. Jurnal Pendidikan Teknologi Dan Kejuruan, 15(2), 277-286.

Sugiyono. (2018). METODE PENELITIAN PENDIDIKAN Pendekatan Kuantitatif, Kualitatif, dan $R \& D$. ALFABETA.

Sulistya, D. A. (2018). Pengembangan Quantum Teaching Berbasis Video Pembelajaran Camtasia Pada Materi Permukaan Bumi Dan Cuaca. Profesi Pendidikan Dasar, 1(2), 169.

Supriatna, A., \& Nurcahyono, N. A. (2017). Etnomatematika : Pembelajaran Matematika Berdasarkan Tahapan- Tahapan Kegiatan Bercocok Tanam Apit Supriatna Novi Andri Nurcahyono. Seminar Nasional Pendidikan Matematika, 26-32. 